\title{
POSSIBLE MECHANISM FOR ZONISAMIDE-INDUCED HYPERAMMONEMIA IN A CHILD WITH CITRULLINEMIA TYPE 1
}

Sir,

Seizures are common symptoms of urea cycle disorders. ${ }^{[1]}$ Choice of antiepileptic 
drugs (AEDs) is limited as many first-line drugs, namely, valproate, carbamazepine, phenobarbitone and topiramate, provoke hyperammonemia and neurological deterioration in these patients. ${ }^{[2-4]}$ Zonisamide (ZNS), an antiepileptic drug belonging to the sulfonamide group, has demonstrated good efficacy and tolerability in children. A possible ZNS-induced hyperammonemia in a child with citrullinemia is described.

An 8-year-old boy was diagnosed with citrullinemia (Online Mendelian Inheritance in Man 215700) in 2001 at 15 months of age on the basis of acute hyperammonemic encephalopathy and gas chromatography/ mass spectrometry (GC/MS) analysis of urine showing elevated levels of orotic acid and citrulline. Tandem mass spectrometry (MS/ MS) of his blood sample revealed elevated levels of citrulline $(555 \mu \mathrm{M}$, normal cutoff is 70 $\mu \mathrm{M})$ and absent arginosuccinate, suggestive of citrullinemia. Since then, he was on an average dietary protein intake of $1 \mathrm{~g} / \mathrm{kg} /$ day and sodium benzoate $(250 \mathrm{mg} / \mathrm{kg} /$ day divided in four equal doses). After discontinuation of sodium benzoate from November 2004, his serum ammonia was controlled with dietary protein restriction alone. The serum ammonia in January 2008 was 78 $\mu \mathrm{g} / \mathrm{dL}$ (normal, 50-150 $\mu \mathrm{g} / \mathrm{dL}$ ).

He presented in August 2008 (day 1) with a history of 3 episodes of intermittent blinking of eyes accompanied by blank staring in the last 3 months. There was no history of generalized seizures. The parents reported anorexia (30\% to $40 \%$ reduction in food intake from the previous recommended level of intake) in the preceding few days. On examination his pulse rate, respiratory rate and BP were 110/ $\mathrm{min}, 28 / \mathrm{min}$ and $110 / 70 \mathrm{~mm} / \mathrm{Hg}$, respectively. His weight, height and head circumference were $20 \mathrm{~kg}\left(3^{\text {rd }}-10^{\text {th }}\right.$ percentile $), 118 \mathrm{~cm}$ ( $3^{\text {rd }}-$ $10^{\text {th }}$ percentile) and $48 \mathrm{~cm}\left(<25^{\text {th }}\right.$ percentile $)$, respectively. He was drowsy and speaking irrelevantly. Systemic examination revealed no abnormality. On day 1 , his serum ammonia was $265 \mu \mathrm{g} / \mathrm{dL}$, blood sugar was $60 \mathrm{mg} / \mathrm{dL}$ and blood gas analysis revealed $\mathrm{pH}-7.45, \mathrm{pCO} 2-$ 24.3 and bicarbonate- 23.5. The serum AST and ALT levels were 31 and 16 , respectively. He was treated with IV fluids (1/3 DNS) (1500 $\mathrm{mL}$ over 24 hours) and oral sodium benzoate (250 mg/kg/day divided in three equal doses). Nasogastric tube feeds (2000 calories) were initiated on day 2 , along with supplementation of branch-chain amino acids, and protein intake was gradually increased to $1.4 \mathrm{~g} / \mathrm{kg} /$ day. As intermittent blinking of eyes accompanied by blank staring was suggestive of petitmal seizures, oral ZNS ( $2 \mathrm{mg} / \mathrm{kg} /$ day) was commenced as an off-label use since valproate was contraindicated and ethosuximide is unavailable in India.

On day 3 (48 hours after ZNS was initiated), he developed vomiting, and the serum ammonia was $491 \mu \mathrm{g} / \mathrm{dL}$. Video EEG performed on day 4 was normal. On day 7 , the sensorium deteriorated, with confusion and multiple episodes of vomiting. The serum ammonia level was $495 \mu \mathrm{g} / \mathrm{dL}$. The persistent hyperammonemia was suspected to be due to ZNS, and the drug was immediately discontinued. The child had a possible adverse drug reaction with ZNS (Naranjo score, 4). ${ }^{[5]}$ Ondansetron (IV, $0.5 \mathrm{mg} / \mathrm{kg} /$ day) and oral lansoprazole (30 mg once a day) were commenced, in addition to arginine powder (400 mg/kg/day divided in three equal doses). 
The serum ammonia level decreased to $380 \mu \mathrm{g} /$ $\mathrm{dL}$ on day $9,267 \mu \mathrm{g} / \mathrm{dL}$ on day $10,176 \mu \mathrm{g} / \mathrm{dL}$ on day 11 and normalized to $87 \mu \mathrm{g} / \mathrm{dL}$ on day 12. Levels of plasma amino acids performed on day 10 were normal. At discharge the sensorium was normal, vomiting had ceased and appetite had improved, with the child demanding food. He was discharged on sodium benzoate, arginine $200 \mathrm{mg} / \mathrm{kg} / \mathrm{day}$ and diet with $1.4 \mathrm{~g} / \mathrm{kg}$ of protein and 2000 calories.

ZNS is structurally and functionally distinct from other AEDs. A wide range of mechanisms of action includes reduction of sustained highfrequency repetitive firing of action potentials by altering the fast inactivation threshold of voltage-dependent sodium channels; and prevention of the spread of seizure discharge by inhibiting low-threshold T-type calcium channels. Additionally, ZNS is a weak inhibitor of carbonic anhydrase. ZNS has been used extensively in children and has been administered to infants as young as 1 month of age. ${ }^{[6]}$ Though it has demonstrated good efficacy and tolerability in children, pediatric use of ZNS is off-label..6] The only unique adverse effects in children are oligohydrosis and hyperthermia. The package insert does not carry a warning of hyperammonemia or lists urea cycle disorders as a precaution. ${ }^{[7]}$ The only association with hyperammonemia was described in 4 cases (incidence 1:1, 222,453 exposures). ${ }^{[8]}$

The role of ZNS in aggravating hyperammonemia in the present case cannot be dismissed. The fact that it inhibits carbonic anhydrase which in turn reduces availability of bicarbonate ion for carbamyl phosphate synthesis is relevant with the knowledge that some diuretics cause hyperammonemia by inhibition of mitochondrial carbonic anhydrase. ${ }^{[9]}$ This report serves to caution physicians prescribing ZNS and encountering hyperammonemia to suspect ZNS as the likely culprit. As the information available on the package insert does not specify hyperammonemia, the drug may not be withdrawn promptly, if the patient develops signs and symptoms suggestive of hyperammonemia.. Moreover, they should educate patients and the parents to recognize such symptoms early and monitor serum ammonia levels in the appropriate circumstances.

AMIR Y. SHAIKH, MAMTA N. MURANJAN', NITHYA J. GOGTAY ${ }^{2}$, KEYA R. LAHIRI ${ }^{1}$ Seth GS Medical College and KEM Hospital, Mumbai, Departments of ${ }^{1}$ Pediatrics and ${ }^{2} \mathrm{Clinical}$ Pharmacology, Seth GS Medical College and KEM Hospital, Mumbai, India

Correspondence: Dr. Amir Y. Shaikh, A/402, Asmita Pearl, Mira Road, Thane, Mumbai - 400 017, India E-mail: amir.s.doc@gmail.com

\section{REFERENCES}

1. Summar M. Current strategies for the management of neonatal urea cycle disorders. J Pediatr 2001;138:S30-9.

2. Dealberto MJ. Valproate-induced hyperammonaemic encephalopathy: Review of 14 cases in the psychiatric setting. Int Clin Psychopharmacol 2007;22:330-7.

3. Ambrosetto G, Riva R, Baruzzi A. Hyperammonemia in asterixis induced by carbamazepine: Two case reports. Acta Neurol Scand 1984;69:186-9.

4. Longin E, Teich M, Koelfen W, König S. Topiramate enhances the risk of valproateassociated side effects in three children. Epilepsia 2002;43:451-4.

5. Naranjo CA, Busto U, Sellers EM, Sandor P, 
Ruiz I, Roberts EA, et al. A method for estimating the probability of adverse drug reactions. Clin Pharmacol Ther 1981;30:239-45.

6. Chung AM, Eiland LS. Use of second-generation antiepileptic drugs in the pediatric population. Paediatr Drugs 2008;10:217-54.

7. Zonegran package insert, 2008. Available from: http://www.fda.gov/cder/foi/ label/2006/020789s019lbl.pdf. [accessed on 2008 Sep 24].
8. Zonisamide details from World Intellectual Property Organization, 2005. Available from: http://www. wipo.int/pctdb/en/wo.jsp?WO2005070424. [accessed on 2008 Sep 25].

9. Häussinger D, Kaiser S, Stehle T, Gerok W. Liver carbonic anhydrase and urea synthesis: The effect of diuretics. Biochem Pharmacol 1986;35:3317-22.

DOI: 10.4103/0019-5359.53168

\section{Announcement}

Dr. J. C. Patel Medical Research Foundation is organizing Fifth Conference on Iron Deficiency at Shanti Sarovar, Hyderaban on 5 -7 February 2010. Early registration closes on 31/8/09. Only first 150 out-station delegates w ould be registered and would be provided free accommodation. Local delegates not requiring accommodation will have unrestricted registration. Last date for submission of abstracts for free papers is $15 / 11 / 09$. All accepted abstracts w ould receive cash awards based on merits.

For details conact: For outstation delegates - Dr. B. C. M ehta, 504, Pracho Society, J uhu-Versova Link Rd, Andheri (W) M umbai 400 053. E-mail iconid2008@ gmail.com Web-site www.ghrc.bk.org 